\title{
Hand Grip Strength in Elderly Rheumatoid Arthritis Patients
}

\author{
Yaşlı Romatoid Artrit Hastalarında El Kavrama Gücü
}

\author{
Aslı ÇALIŞKAN UÇKUN ${ }^{1}$ \\ (D) 0000-0002-2492-4852 \\ Ayşegül ALTUN GÜVENIR ${ }^{2}$ \\ (D) 0000-0003-4680-7478 \\ Fatma Gül YURDAKUL ${ }^{1}$ \\ (D) 0000-0001-8630-9233 \\ Tuba GÜLER ${ }^{1}$ \\ (D) 0000-0002-7986-931X \\ Filiz SIVAS ${ }^{1}$ \\ (1) 0000-0003-1705-9028 \\ Hatice BODUR ${ }^{1}$ \\ (D) 0000-0003-3308-7007
}

\footnotetext{
${ }^{1}$ Ankara City Hospital Physical Medicine and Rehabilitation Clinic, Ankara, Turkey

${ }^{2}$ Ankara Physical Medicine and Rehabilitation Training and Research Hospital, Ankara, Turkey
}

\section{Sorumlu Yazar \\ Corresponding Author Aslı ÇALIŞKAN UÇKUN draslical@gmail.com}

Gelis Tarihi / Received : 08.10.2019 Kabul Tarihi / Accepted : 08.12.2019 Çevrimiçi Yayın Tarihi / Available Online

\begin{abstract}
Aim: Previous studies have shown that rheumatoid arthritis and aging are independent risk factors for decreased hand grip strength. However, little is known about how coexisting rheumatoid arthritis would affect the reduced hand grip strength in the elderly population. Therefore, the aims of this study were to compare the hand grip strength of elderly female rheumatoid arthritis patients with controls and to investigate the factors associated with hand grip strength in the patients with rheumatoid arthritis.

Material and Methods: This cross-sectional study included 45 elderly women with rheumatoid arthritis and 43 age-matched controls. All subjects were provided with selfreported questionnaires measuring physical disability, anxiety and depression, sleep quality, cognitive impairment, and fatigue severity. Hand grip strength was measured with hand dynamometer. The disease activity was assessed by the Disease Activity Score.

Results: There were no significant differences in values of age, body mass index, physical disability, anxiety and depression, sleep quality, cognitive impairment, fatigue severity, and grip strength between the groups. Disease period, physical disability, and disease activity were variables which showed statistically significant negative correlation with grip strength in rheumatoid arthritis patients. In further linear regression analysis, it is found that only long disease duration was associated with decreased grip strength.

Conclusion: Rheumatoid arthritis does not seem to significantly affect aging-related muscle strength loss. Disease duration was found to be the only independent factor associated with hand grip strength in elderly rheumatoid arthritis patients.

Keywords: Hand strength; rheumatoid arthritis; sarcopenia.
\end{abstract}

ÖZ

Amaç: Önceki çalışmalar romatoid artritin ve yaşlanmanın, azalmış el kavrama gücü için bağımsız risk faktörleri olduğunu göstermiştir. Bununla birlikte, bir arada var olan romatoid artritin yaşlı popülasyondaki azalmış el kavrama gücünü nasıl etkileyeceği konusunda çok az şey bilinmektedir. Bu nedenle, bu çalışmanın amaçları, yaşlı kadın romatoid artritli hastaların el kavrama gücünü kontrollerle karşılaştırmak ve romatoid artrit hastalarında el kavrama gücü ile ilişskili faktörleri araștırmaktır.

Gereç ve Yöntemler: Bu kesitsel çalışmaya 45 romatoid artritli yaşlı kadın ve 43 yaşa göre eşleştirilmiş kontrol dahil edildi. Tüm deneklere fiziksel özürlülük, anksiyete ve depresyon, uyku kalitesi, bilişsel bozulma ve yorgunluk şiddetini ölçen kendi kendine bildirilen anketler verildi. El kavrama gücü, el dinamometresi ile ölçüldü. Hastalık aktivitesi, Hastalık Aktivite Skoru ile değerlendirildi.

Bulgular: Gruplar arasında yaş, vücut kitle indeksi, fiziksel özürlülük, anksiyete ve depresyon, uyku kalitesi, bilișsel bozulma, yorgunluk șiddeti ve kavrama gücü değerleri açısından anlamlı fark yoktu. Hastalık süresi, fiziksel özürlülük ve hastalık aktivitesi romatoid artrit hastalarında kavrama kuvveti ile istatistiksel olarak anlamlı düzeyde negatif korelasyon gösteren değişkenlerdi. Sonraki doğrusal regresyon analizinde, sadece uzun hastalık süresinin kavrama kuvvetinin azalması ile ilişkili olduğu bulundu.

Sonuç: Romatoid artrit, yaşlanmaya bağlı kas kuvveti kaybını önemli ölçüde etkilemiyor gibi görünmektedir. Hastalık süresi, yaşlı romatoid artrit hastalarında el kavrama gücü ile ilişkili tek bağımsız faktör olarak bulunmuştur.

Anahtar kelimeler: El gücü; romatoid artrit; sarkopeni. 


\section{INTRODUCTION}

Hand grip strength (HGS) defines the strength of the hand muscles used to grip (1). HGS, measured by manual dynamometry, has been recommended in the clinical practice as an easy measure in the definition of musculoskeletal function, as well as of disability (2). Especially in diseases that affect hands such as rheumatoid arthritis (RA), measuring HGS is of paramount importance. HGS in RA patients was demonstrated to be lower than controls (3). Another important condition that is known to be independently associated with reduced HGS is sarcopenia, which is described as age-related loss of muscle function and mass (4). However, it has not yet been fully discussed how coexisting RA would affect the reduced HGS in the elderly population.

It has been shown that decreased HGS in RA was associated with a variety of factors, including disease severity, pain, deformity, loss of joint range, functionality, joint damage, fatigue, sleep quality $(3,5,6)$. However, studies regarding factors associated with decreased HGS in the elderly RA population are lacking (7).

Therefore, the purposes of the current study were to measure the HGS of elderly participants with RA, compared with controls, and to exam the factors associated with HGS in elderly RA patients.

\section{MATERIAL AND METHODS \\ Participants}

This cross-sectional case-control study was conducted with elderly female patients with RA followed up at least 1 year at the Physical Medicine and Rehabilitation outpatient clinic, Ankara Numune Training and Research Hospital, Turkey. Female controls matched by age were selected from patients' friends or family members. This study was approved by the Clinical Researches Ethics Committee of Ankara Numune Training and Research Hospital (dated 04.10.2018 and numbered 2246) and all individuals provided written informed.

Participants 65 years old or older were included. RA patients had to fulfill the criteria formulated by the American College of Rheumatology and the European League against Rheumatism in 2010 (8). The exclusion criteria were as follows: a history of a neuromuscular disorder, including carpal tunnel syndrome and polyneuropathy, or orthopedic disorder or a history of hand surgery that may impair hand function. Participants with unstable myocardial ischemia, significant anemia (hemoglobin $<11 \mathrm{~g} / \mathrm{dl}$ ), severe renal failure, diabetes mellitus, malignancy, and smokers were also excluded.

Data on demographics, age (year), disease period (year), body mass index (BMI) $(\mathrm{kg} / \mathrm{m} 2)$, swollen and tender joint counts, visual analogue scale (VAS), and C-reactive protein (CRP) values were recorded.

\section{Assessment of Functional Ability}

Disability was evaluated by the Health Assessment Questionnaire (HAQ) $(9,10)$. It is performed using a fourpoint scale $(0=$ no problems, $3=$ unable to do) to score participants performing 8 categories of daily living activities. Assessment of Disease Activity

It was measured by using the Disease Activity Score 28CRP (DAS28-CRP) (11).

Assessment of Anxiety and Depression

We used the validated Turkish version of Hospital Anxiety and Depression Scale (HADS) to detect the level of anxiety and depression. It is a fourteen item scale (seven questions for anxiety and seven questions for depression) $(12,13)$.

\section{Assessment of Sleep Quality}

The Turkish version of the Pittsburgh Sleep Quality Index (PSQI) was performed to assess sleep quality. The PSQI is an 18-item self-reported instrument to evaluate sleep quality, sleep onset latency, sleep efficiency, sleep length, sleep deprivation, daytime dysfunction, and use of pills for sleeping. Higher scores than 5 indicate poorer sleep quality (14).

\section{Assessment of Cognitive Impairment}

We used the Mini-Mental State Examination (MMSE) questionnaire (range 0-30) to assess cognitive function. Lower scores than 25 indicate cognitive impairment $(15,16)$.

\section{Assessment of Fatigue Severity}

The Turkish version of the Fatigue Severity Scale (FSS) was used to assess fatigue symptoms. It was a self-reported 9-item scale with scores ranging between 1 and 7 per item (1=completely disagree, $\quad 7=$ completely agree). Pathological fatigue was defined as "FSS $\geq 4 / 9$ " $(17,18)$.

\section{Measurement of Hand Grip Strength}

HGS was measured using a manual hand dynamometer (Sammons Preston, Inc., Bolingbrook, IL, USA) by the same examiner to prevent the inter-observer error. It was evaluated with the patients sitting on a chair, with $90^{\circ}$ elbow flexion, forearms and wrists in a neutral position. The participants were instructed to squeeze the handle as hard as possible during the measurements. Three evaluations were made for each hand, and the mean value was recorded in kilograms (kg) (19).

\section{Statistical Analysis}

Shapiro-Wilk test was used to test normality assumption. Mann-Whitney U test was applied for comparison of groups in terms of variables not meet the normality assumption, while Student's t test was used for variables showing normal distribution. Descriptive statistics were given as mean \pm standard deviation and median (minimummaximum) values. Spearman's correlation analysis was utilized to analyze correlation between the HGS and age, BMI, disease duration, PSQI, MMSE, FSS, HADSdepression, HADS-anxiety, HAQ, and DAS28-CRP values. Multiple linear regression analysis was used for significantly correlated variables in the univariate analysis to assign independent factors of HGS in RA patients. According to the univariate analysis, three variables including disease duration, HAQ, and DAS28-CRP were entered into the regression model. Data were analyzed using the SPSS v. 17 statistical package and p values $<0.05$ were considered statistically significant.

\section{RESULTS}

Among 88 participants, 45 were in RA group with a mean age of $73.1 \pm 3.2$ years; 43 in control group with a mean age of $72.5 \pm 3.2$ years. The participants in RA and control groups had similar age, BMI, and scores of PSQI, MMSE, FSS, HADS-depression, HADS-anxiety, and HAQ. The mean HGS for dominant hand in RA and control groups were $18.8 \pm 7.0 \mathrm{~kg}$ and $21.2 \pm 5.4 \mathrm{~kg}$, respectively, and there was not a statistically significant difference between groups $(\mathrm{p}=0.082$, Table 1$)$. 
In RA group, the mean period of RA disease was $12.4 \pm 7.8$ years and DAS28-CRP score was 2.8 \pm 1.2 . When we compare the dominant HGS with all parameters, a significant negative correlation was found between HGS and disease duration $(\mathrm{r}=-0.336, \mathrm{p}=0.028), \mathrm{HAQ}(\mathrm{r}=-0.209$, $\mathrm{p}=0.023)$ and DAS28-CRP $(\mathrm{r}=-0.324, \mathrm{p}=0.035)$. There was no correlation between HGS with the age, BMI, and scores of PSQI, MMSE, FSS, HADS-depression, and HADS-anxiety (Table 2). Further evaluation by using multiple linear regression analysis with enter procedure was applied with the variables that were significant in univariate analyses. Even though there was significant association among HGS and disease duration, HAQ, DAS28-CRP in univariate analysis, regression analysis revealed that only disease duration had an independent effect on HGS values ( $p=0.009, \mathrm{R}^{2}=0.250$, Table 3 ).

\section{DISCUSSION}

It has been shown that, independently of each other, RA and aging have impacted on HGS negatively. However, the effect of RA on HGS in the elderly population has not been fully addressed. To clarify this, we compared the HGS between aging individuals with RA and age-matched healthy controls, and we found similar values in both groups. In addition, using a multiple linear regression analysis, we demonstrated that only disease duration was associated with HGS in the elderly population with RA.

Our finding of no significant difference in HGS for both groups is clearly inconsistent with other studies which reported that the participants with RA had significantly lower HGS than healthy controls $(5,20)$. Firstly, it has been shown that HGS can be affected by functional ability, sleep quality, anxiety and depression, cognitive impairment, fatigue; therefore, we also evaluated the groups in terms of these factors to prevent bias and found no significant difference $(3,21)$. Perhaps, we cannot fully explain this discrepancy; however, this may be due to some factors. One reason for this may be explained by selection as elderly RA patients with severe muscle weakness had less willingness to participate in the study. As a matter of fact, RA participants in our study generally tended to have low disease activity. As a second reason, advances in management with improvement of patient outcomes might influence HGS positively, therefore, it may not be rational to compare the results with those of previous studies that was done in the pre-biologics era. The etiopathogenesis of sarcopenia is complex and includes numerous factors, including hormonal, inflammatory, metabolic factors (22). Similar to the RA pathogenesis, inflammatory cytokines have been demonstrated to have a substantial role in the pathogenesis of sarcopenia. We can speculate that drugs used for RA to suppress inflammatory cytokines may also suppress these cytokines in the process of sarcopenia and so causes less muscle strength loss than expected in elderly RA patients. The inverse association between inflammation and HGS requires further exploration. For example, the question of whether using inflammation-suppressing drugs in healthy aging population to prevent sarcopenia should be investigated. In our study, we found the correlation between HGS and DAS28, HAQ, and disease duration in RA group. However, after linear regression analysis, we found that duration of RA disease was the only independent factor
Table 1. Socio-demographic data of participants

\begin{tabular}{|c|c|c|c|}
\hline & $\underset{n=45}{R A}$ & $\begin{array}{c}\text { Control } \\
n=43\end{array}$ & $\mathbf{p}$ \\
\hline Age, years & $\begin{array}{c}73.1 \pm 3.2 \\
74(65-77)\end{array}$ & $\begin{array}{c}72.5 \pm 3.2 \\
73(65-77)\end{array}$ & 0.348 \\
\hline $\begin{array}{l}\text { Body mass index, } \\
\mathrm{kg} / \mathrm{m}^{2}\end{array}$ & $\begin{array}{c}29.4 \pm 5.5 \\
28(22-48)\end{array}$ & $\begin{array}{c}29.6 \pm 5.7 \\
28(18-47)\end{array}$ & 0.841 \\
\hline $\begin{array}{l}\text { HGS, kg } \\
\text { (dominant hand) }\end{array}$ & $\begin{array}{l}18.8 \pm 7.0 \\
19(6-35)\end{array}$ & $\begin{array}{c}21.2 \pm 5.4 \\
22(10-32)\end{array}$ & 0.082 \\
\hline $\begin{array}{l}\text { HGS, kg } \\
\text { (nondominant hand) }\end{array}$ & $\begin{array}{l}18.8 \pm 7.1 \\
18(8-35)\end{array}$ & $\begin{array}{c}20.9 \pm 5.9 \\
20(10-32)\end{array}$ & 0.113 \\
\hline PSQI & $\begin{array}{l}7.2 \pm 3.6 \\
6(0-17)\end{array}$ & $\begin{array}{l}8.2 \pm 4.3 \\
9(0-18)\end{array}$ & 0.220 \\
\hline MMSE & $\begin{array}{c}20.1 \pm 3.8 \\
21(10-27)\end{array}$ & $\begin{array}{c}21.3 \pm 4.1 \\
21(10-29)\end{array}$ & 0.164 \\
\hline FSS & $\begin{array}{l}4.0 \pm 2.2 \\
3(1-8)\end{array}$ & $\begin{array}{l}4.3 \pm 1.9 \\
5(1-8)\end{array}$ & 0.568 \\
\hline HADS-Depression & $\begin{array}{l}7.2 \pm 5.1 \\
7(0-17)\end{array}$ & $\begin{array}{l}8.5 \pm 4.7 \\
8(1-21)\end{array}$ & 0.650 \\
\hline HADS-Anxiety & $\begin{array}{l}7.6 \pm 4.1 \\
8(1-18)\end{array}$ & $\begin{array}{l}8.0 \pm 4.1 \\
8(1-17)\end{array}$ & 0.201 \\
\hline HAQ & $\begin{array}{c}1.0 \pm 0.9 \\
0.7(0-3)\end{array}$ & $\begin{array}{c}0.9 \pm 0.6 \\
0.6(0-3)\end{array}$ & 0.967 \\
\hline
\end{tabular}

RA: Rheumatoid Arthritis, PSQI: Pittsburgh Sleep Quality Index, MMSE: MiniMental State Examination, FSS: Fatigue Severity Scale, HADS: Hospital Anxiety and Depression Scale, HAQ: Health Assessment Questionnaire, Descriptive statistics given as mean \pm standard deviation, median (minimum-maximum)

Table 2. Correlations between handgrip strength and socio-demographic and clinical variables in RA patients

\begin{tabular}{lcc}
\hline & $\begin{array}{c}\text { Correlation } \\
\text { Coefficient }\end{array}$ & $\mathbf{p}$ \\
\hline Age & -0.063 & 0.681 \\
Body mass index & 0.092 & 0.546 \\
Disease duration & -0.336 & $\mathbf{0 . 0 2 8}$ \\
PSQI & -0.221 & 0.145 \\
MMSE & 0.125 & 0.412 \\
FSS & -0.159 & 0.297 \\
HADS-Depression & -0.188 & 0.217 \\
HADS-Anxiety & -0.100 & 0.514 \\
HAQ & -0.209 & $\mathbf{0 . 0 2 3}$ \\
DAS28-CRP & -0.324 & $\mathbf{0 . 0 3 5}$ \\
\hline
\end{tabular}

RA: Rheumatoid Arthritis, PSQI: Pittsburgh Sleep Quality Index, MMSE: MiniMental State Examination, FSS: Fatigue Severity Scale, HADS: Hospital Anxiety and Depression Scale, HAQ: Health Assessment Questionnaire, DAS28-CRP: Disease Activity Score 28-CRP

Table 3. Relationship between hand grip strength and clinical variables in RA patients

\begin{tabular}{llccccc}
\hline & & B & SE & p & \multicolumn{2}{c}{ 95\% } \\
\hline \multirow{3}{*}{ Grip } & Disease duration & -0.263 & 0.122 & $\mathbf{0 . 0 3 7}$ & -0.509 & -0.016 \\
Strength & HAQ & -1.931 & 1.126 & 0.094 & -4.207 & 0.344 \\
& DAS28-CRP & -1.359 & 0.786 & 0.092 & -2.948 & 0.230 \\
\hline
\end{tabular}

B: Regression coefficient, SE: Standard Error, CI: Confidence Interval, HAQ Health Assessment Questionnaire, DAS28-CRP: Disease Activity Score 28-CRP 
associated with HGS. The present study confirms previously reported inverse relationship between HGS and disease duration $(6,22-24)$. In these previous studies, HGS was also associated with several other factors such as disease activity, functional status, or radiological damage $(6,23,24)$. However, the subsequent regression analysis was not performed in these studies. Duration of the disease might better reflect joint damage, inflammatory burden, which may accumulate over time, and so that may led to decreased HGS.

There are some limitations of this study. First, we cannot eliminate the impact of individual motivation in HGS tests. Second, our sample is composed of female; therefore, the results may not be generalized to the general population. In conclusion, we found that no significant difference in HGS between elderly individuals with RA and controls and the duration of RA disease was only independent factor associated with HGS in RA patients.

\section{REFERENCES}

1. Bohannon RW. Quantitative testing of muscle strength: issues and practical options for the geriatric population. Top Geriatr Rehabil. 2002;18(2):1-17.

2. Bohannon RW, Magasi S. Identification of dynapenia in older adults through the use of grip strength t-scores. Muscle Nerve. 2015;51(1):102-5.

3. Higgins SC, Adams J, Hughes R. Measuring hand grip strength in rheumatoid arthritis. Rheumatol Int. 2018;38(5):707-14.

4. Syddall H, Cooper C, Martin F, Briggs R, Aihie Sayer A. Is grip strength a useful single marker of frailty? Age Ageing. 2003;32(6):650-6.

5. Sferra da Silva G, de Almeida Lourenço M, de Assis MR. Hand strength in patients with RA correlates strongly with function but not with activity of disease. Adv Rheumatol. 2018;58:20.

6. Dedeoğlu M, Gafuroğlu Ü, Yilmaz Ö, Bodur H. The relationship between hand grip and pinch strengths and disease activity, articular damage, pain and disability in patients with rheumatoid arthritis. Turk J Rheumatol. 2013;28(2):69-77.

7. Petchiappan V, Selvam S, Dhanush M, Prabu N. Assessment of handgrip strength in patients with rheumatoid arthritis and fibromyalgia-do they differ? An observational study. Arch Med Vol. 2018;10(4):3.

8. Aletaha D, Neogi T, Silman AJ, Funovits J, Felson DT, Bingham CO 3rd, et al. 2010 rheumatoid arthritis classification criteria: an American College of Rheumatology/European League Against Rheumatism collaborative initiative. Arthritis Rheum. 2010;62(9):2569-81.

9. Fries JF, Spitz P, Kraines RG, Holman HR. Measurement of patient outcome in arthritis. Arthritis Rheum. 1980;23(2):137-45.

10. Kucukdeveci AA, Sahin H, Ataman S, Griffiths B, Tennant A. Issues in cross-cultural validity: example from the adaptation, reliability, and validity testing of a Turkish version of the Stanford health assessment questionnaire. Arthritis Rheum. 2004;51(1):14-9.

11. Prevoo ML, van't Hof MA, Kuper HH, van Leeuwen MA, van de Putte LB, van Riel PL. Modified disease activity scores that include twenty-eight-joint counts. Development and validation in a prospective longitudinal study of patients with rheumatoid arthritis. Arthritis Rheum. 1995;38(1):44-8.

12. Zigmond AS, Snaith RP. The hospital anxiety and depression scale. Acta Psychiatr Scand. 1983;67(6):361-70.

13. Aydemir Ö, Güvenir T, Küey L, Kültür S. Validity and reliability of Turkish version of hospital anxiety and depression scale. Turk J Psychiatry. 1997;8(4):280-7.

14. Ağargün MY, Kara H, Anlar Ö. The validity and reliability of the Pittsburgh sleep quality index. Turk $\mathbf{J}$ Psychiatry. 1996;7(2):107-15.

15. Folstein MF, Folstein SE, McHugh PR. "Mini-mental state": a practical method for grading the cognitive state of patients for the clinician. J Psychiatr Res. 1975;12(3):189-98.

16. Güngen C, Ertan T, Eker E, Yaşar R, Engin F. Reliability and validity of the standardized mini mental state examination in the diagnosis of mild dementia in Turkish population. Turk J Psychiatr. 2002; 13(4): 27381.

17. Krupp LB, LaRocca NG, Muir-Nash J, Steinberg AD. The fatigue severity scale. Application to patients with multiple sclerosis and systemic lupus erythematosus. Arch Neurol. 1989;46(10):1121-3.

18. Armutlu K, Korkmaz NC, Keser I, Sumbuloglu V, Akbiyik DI, Guney Z, et al. The validity and reliability of the fatigue severity scale in Turkish multiple sclerosis patients. Int J Rehabil Res. 2007;30(1):81-5.

19. Mathiowetz V, Weber K, Volland G, Kashman N. Reliability and validity of grip and pinch strength evaluations. J Hand Surg Am. 1984;9(2):222-6.

20. Alomari MA, Keewan EF, Shammaa RA, Alawneh K, Khatib SY, Welsch MA. Vascular function and handgrip strength in rheumatoid arthritis patients. Sci World J. 2012;2012:580863.

21. Innes EV. Handgrip strength testing: a review of the literature. Aust Occup Ther J. 1999;46(3):120-40.

22. Beenakker KG, Ling CH, Meskers CG, de Craen AJ, Stijnen T, Westendorp RG, et al. Patterns of muscle strength loss with age in the general population and patients with a chronic inflammatory state. Ageing Res Rev. 2010;9(4):431-6.

23. Palamar D, Er G, Terlemez R, Ustun I, Can G, Saridogan M. Disease activity, handgrip strengths, and hand dexterity in patients with rheumatoid arthritis. Clin Rheumatol. 2017;36(10):2201-8.

24. Bodur H, Yilmaz O, Keskin D. Hand disability and related variables in patients with rheumatoid arthritis. Rheumatol Int. 2006;26(6):541-4. 